Renée Koch Piettre

\title{
Anthropomorphism, Theatre, Epiphany: From Herodotus to Hellenistic Historians
}

\begin{abstract}
This paper argues that, beginning with the Euripidean deus ex machina, dramatic festivals introduced a new standard into epiphanic rituals and experience. Through the scenic double énonciation, gods are seen by mythical heroes as gods, but by the Athenian spectators as costumed actors and fictive entities. People could scarcely believe these were 'real' gods, but would have no doubt been impressed by the scenic machinery. Thus the Homeric theme of a hero's likeness to the gods developed into the Hellenistic theme of the godlike ruler's (or actor's) theatrical success (or deceit). So in the Athenians' Hymn to Demetrius Poliorcetes, a victorious ruler entering a city is welcomed as a better god than the gods themselves. The simultaneous rise in popularity of paradoxical stories and experiences in the Hellenistic period was grounded not in believing, but in disbelieving-a phenomenon associated with antiquarian interests, the self-publicity of religious sanctuaries, or amazed credulity. People were increasingly drawn to 'real' gods, leading to long pilgrimages and extensive financial outlay (in the mysteries) in order to see them. I investigate this phenomenon by focusing upon fragments of the 'mimetic' or 'tragic' Greek historians that survive from this period.
\end{abstract}

This paper explores whats seems to be a growing internal change in Greek religion between the fifth and third centuries $\mathrm{BC}-\mathrm{a}$ progressive shift from performance (when ritual acts by itself, its spectacular character remaining optional) to spectacle (when people put emphasis on impressive delusion, in order to strengthen the reliability of ritual acting), or from ritual drama to the mimetic spectacle of lifelike, plausible appearances. Our aim is to identify a kind of terminus post quem of this change by looking to epiphanic ritual, theatrical mise en scène and individual experience. We argue that while godlike men and women-as well as gods in human form-feature in texts from archaic poetry to the Roman novel, earlier texts emphasize the role of divine grandeur, gods' trickery or ritual performance ${ }^{1}$ in such manifestations, while Hellenistic and Greek Imperial texts emphasize the role of illusion, or, conversely, the enduring nature of the divine.

1 Grandeur: see e.g. Hom. Hymn to Dem. 275-280; trickery: see the disguised gods in the epics; ritual performance: see in the Hom. Hymn to Dem. 273ss. the goddess “teaching her rites". 


\section{Athena and Peisistratus, epiphany and human trickery}

Let us first address Herodotus' (in)famous passage about Peisistratus' second return to Athens (1.60). ${ }^{2}$ The historian tells us that the tyrant contrived an odd trick in order to deceive the Athenians and so convince them to restore his former sovereignty. He and his followers armed and placed in a chariot a tall, handsome woman called Phye, from the district of Paiania. ${ }^{3}$ Pretending that Phye (who was equipped "with all the paraphernalia to make a most impressive spectacle") was Athena herself, they thus conveyed Peisistratus back to the city. ${ }^{4}$ The Athenian townsfolk believed

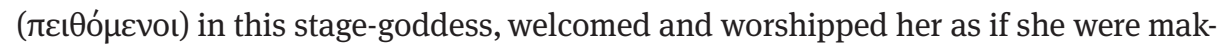

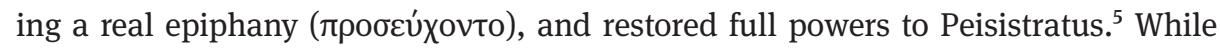
Herodotus seems to present the tale as fact, he also employs various devices to distant himself from the event. ${ }^{6}$ Most strikingly, he expresses surprise, professing to have assumed that the Greek race as a whole, and the Athenians in particular (at

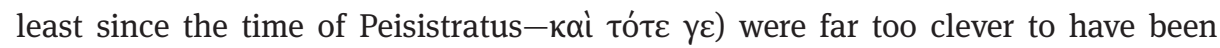
fooled in this way; they would neither have contrived such a foolish trick ( $\mu \eta \chi \alpha v \tilde{\omega} v$ -

2 See especially Connor 1987, Sinos 1993 and Tuci 2004, with bibliography.

3 Cf. comm. by How \& Wells 1912, ad loc.: "i.e. with helmet, breastplate, spear, and shield, as in the familiar Athene statues; see also 4.180 .3 for the investing of a mortal [a very beautiful young girl] with these attributes of [the Libyan] Athene”. All quotations from Herodotus's text are from Legrand's edition (1960). [Arist.] Ath. Pol. 16 refers to "a Thracian flower-girl from Collytus named Phye”; according to Kleidemos FGrH 323 F 15, Phye was the daughter of one Socrates and became the wife of Hipparchus (cf. Ath. 13.609c, who follows Phylarchus, on whom see below). See also Val. Max. 1.2, ext. 2 and Polyaenus Strat. 1.21.1: here Peisistratus, after a battle against Pallenis in Attica, was admitted into the city because he ordered his men to crown themselves as if they had already made a truce with the group of enemies they had first defeated; so the beautiful escort Physa, accoutred in the armor of Pallas, impressed the Athenians, but was not the first reason (nor the first trickery) by which Peisistratus obtained the sovereignty of Athens.

4 See also [Arist.] Ath. Pol. 14.4-5: "Peisistratus drove in a chariot with the woman standing at his

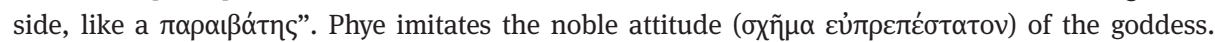

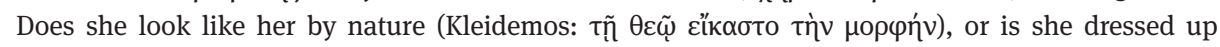

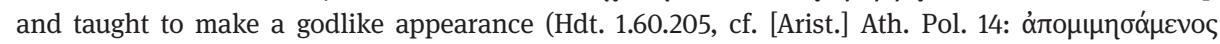
$\tau \tilde{\omega}$ kó $\sigma \omega \omega)$ ? The name đún ('growth' or 'stature') hints at godlike nature, but Herodotus stresses the girl's human status ( gests excessive vanity (1.21.1). See Flory 1987, $180-1$ n. 8, on Herodotus' fondness for pun names.

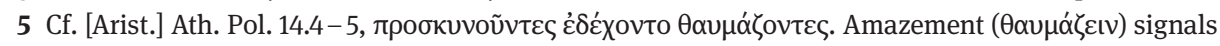
an epiphany. On the phenomenology of $\theta \alpha \tilde{u} \mu \alpha$ see Prier (1989).

6 See Stein 1968 and Maurizi 2003. Fehling 1989, 218 points to devices familiar from fictional narrative, e.g. the name Phye is just the right name for a woman with godlike stature, while Peisistratus' ten years eviction from Athens (1.62) recalls the ten years of the Trojan war. Pritchett 1993, 75 claims that Herodotus "treats the story of Peisistratus as a piece of silliness. While discarding the miracle, he lets it softly down into a story quasi-historical and not intrinsically incredible”. 
$\tau \alpha \mathrm{l}$ ), nor have been taken in by such an obvious fraud. ${ }^{7}$ Gods may appear and give their advice to men, but a woman dressed and looking like a goddess remains a woman. ${ }^{8}$

We have no certainty about the story, ${ }^{9}$ but there is no reason why we should be more skeptical than Herodotus himself, reject the tale, and reconstruct a new, more plausible one. Scholars have argued that Peisistratus may have lost Athenian sovereignty only once, and that his return accompanied by Athena in fact happened after his victory over Athenian citizens at Pallene, less than four miles from the district of Paiania near the temple of Athene Pallenis (1.62). ${ }^{10}$ But this second return looks neither more historical nor less mythical than the first one. Pallene is in fact a site associated with local myth, where Theseus defeated the Pallantides and Eurystheus was killed in a battle against Iolaos, the sons of Heracles and the Athenians; we know also of a gigantomachic exploit involving Athena at Pallene, recorded by the Atthidograph Amelesagoras. ${ }^{11}$ Indeed, Peisistratus won near Pallene with the gods' manifest approval, encouraged (Herodotus tells us) by divinely-inspired prophecy

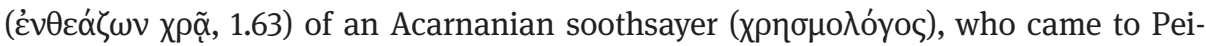
sistratus driven by a “divine” escort or impulse $(\theta$ cín $\pi о \mu \pi \tilde{n}) .{ }^{12}$ Significantly, Herodo-

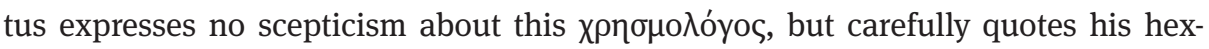
ametric oracle. ${ }^{13}$ Now we are perfectly at liberty to suppose Peisistratus himself returned to Athens (no matter in which circumstances or how many times) according

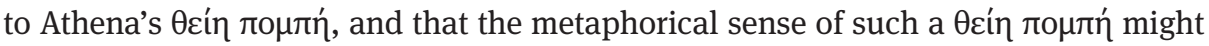
have shifted to something more concrete, perhaps with the help of an allegoric

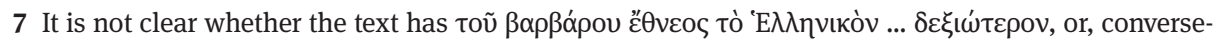

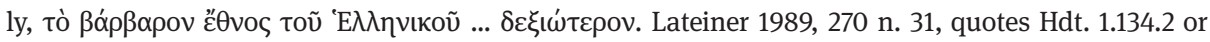

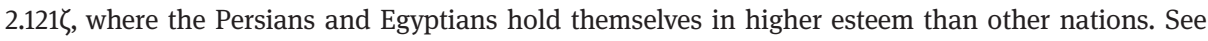
also Sourvinou-Inwood 2003b.

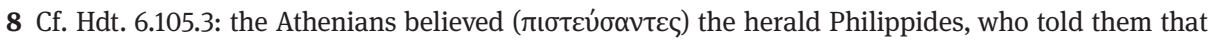

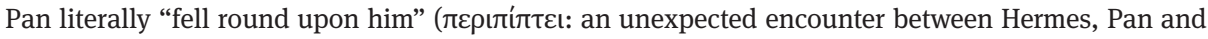
heralds). Here Herodotus does not openly criticize Athenians' credulity (though see Harrison 2000, 90: "the evidence for his belief in epiphanies is surely weak", and Gould 1994 on Herodotus' use of oratio obliqua at 6.105.3 in order to distance himself from a reported tradition).

9 Though Connor 1987, $42-47$ and Sinos 1993, 83-88, have established the historicity of the device in Greek culture; see also Garland 1992, 16ff., 30, 185 n. 17.

10 Following Polyaenus Strat. 1.21.1 (above, n. 2). See Meyer 1899, 248.

11 Theseus: Plut. Thes. 13; Eurystheus: Strabo 8.6.19 = C 377; Amelesagoras FGrH 330 F 1 (Antigon. Hist. Mir. 12). On the temple of Athena Pallenis see Eur. Heracl. 849, 1031 and Ath. 6.234-35a.

12 On this phrase see Block 2000.

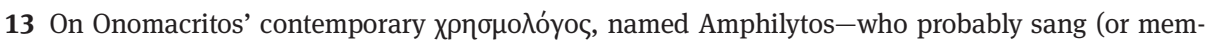
orized) from a book of collected oracles-see also Clem. Al. Strom. 398, [Plat.] Theag. $124 \mathrm{~d}$ (where he is called a $\chi \rho \eta \sigma \mu \omega \delta o ́()$ ), Aristid. Or. 29.22 D. (Jebb p. 373 1. 16) = v.40 Lenz and Themist. Or. 2.26c, 3.46ab, 10.235a. Compare Hdt. 7.6 and Thuc. 2.8.2). Another Acarnanian mantis appears at Hdt. 7.221. Pausanias (9.31.5, see also 3.13.4) writes that "Hesiod learnt seercraft from the Acarnanians"; Peisistratus and his sons were reportedly very fond of oracles; Peisistratus himself was nicknamed Bacis (schol. Ar. Pax 1071). 
monument depicting the goddess as a chariot-ruler (ivíoxoৎ) with Peisistratus at her side as a $\pi \alpha \rho \alpha \beta \alpha$ 'тns. ${ }^{14}$ Nevertheless, we must still explain Herodotus' derisive attitude to the episode.

There was in fact no reason to question the reliability and sincerity of a procession including a man, woman or young girl (generally a priest or a priestess) in the costume of a deity; we do not lack parallels until the time of Pausanias, at least. ${ }^{15}$ These costumes, like those worn by actors of sacred dramas in mystic rites of initiation, were not thought as theatrical, but as presenting 'real' gods (really acting as gods, of course, in the eyes and for the benefit of the religious community). For the general populus, epiphany was perhaps understood in terms of such experiences: emotion at the approach of a procession accompanied by shouting heralds and sacrificial animals, pipers and drummers, and well-dressed boys and girls, followed by anxiety and rapturous joy at the arrival of the long-desired, praised and welcomed god, made present in the form of an anthropomorphic image, a talismanic object or an human actor. ${ }^{16}$ Callimachus' Hymn to Athena, while distanced by its mimetic frame from actual practice, may nevertheless give us a sense of such excitement. ${ }^{17}$

Furthermore, if the story Herodotus relates is true, does it matter whether the audience knew that a girl was disguised or not? ${ }^{18}$ One might argue that the duality of performance generated a special ontological space that allowed for the girl's simultaneous identity as mortal actor and immortal goddess. Here cross-cultural comparison suggests that such duality in processional and ritual contexts is possible and widespread, despite western scepticism. We may observe in India or in Nepal today the worship of masked gods, during which the disguised persons feel as if they really 'are' divinities, and for which there exist specific ritual gestures that establish the very moment of the gods' arrival within his or her mortal 'vessel'. ${ }^{19}$ So

14 For this explanation see Stein 1968, 72 n. 20, Else 1957, $36 \mathrm{ff}$. and Connor 1987, 43. Athena is al-

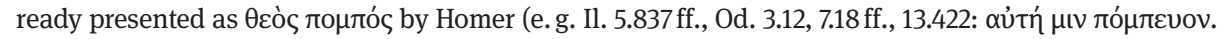
Plut. Sol. 30. 95d includes an anecdote in which Peisistratus is said to have modelled himself on

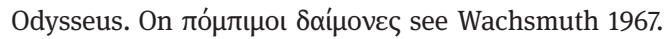

15 E.g. Paus. 7.18.12 (Artemis Laphria) and 9.22.1 (Hermes in Tanagra): see Back 1883; Deubner 1966, 107-109 and Kiechle 1970. We have also plenty of ethnographic evidence from other cultures on this topic.

16 Cancik 1990 stresses this aspect. See also Bettinetti 2001, ch. 6, "Processione”.

17 See e.g. Calame 1991, Henrichs 1993 and Koch Piettre 2001, 220 - 22.

18 Connor 1987, 44, quoted by Sinos 1993, 83-84: "His view of the onlookers as participating in the drama rather than being manipulated by a deceptive disguise is an important advance in our understanding of this sort of ritual.” Sinos compares the episode with Xenophon of Ephesus, 1.2.7, stating that for the Athenian onlookers "the playacting is transparent", while conversely the whole Ephesian community ideally participates in the illusion and "is transformed by the experience of divine presence"; yet this difference is largely due to that between history (Herodotus tells what happened) and fiction (Xenophon of Ephesus stresses the emotional involment of the spectators).

19 See e.g. Toffin 1999, 244-248 on Nepal, and esp. 238 ff.: "Les petites déesses vivantes ... de castes bouddhistes ... sont considérées comme des représentations à part entière des déesses ... Choisies 
we may argue that if Peisistratus wanted to deceive the Athenians, his plan could only have been half a deception: Phye was not simply a woman but a 'real' goddess for the duration of the procession, and, just as at the battle of Pallene, it would have been as necessary for Peisistratus to believe in her as to trust his own lucky star. After all, deception lies at the very heart of epiphany, as Homeric scenes of divine disguise suggest. ${ }^{20}$ Such trickery is never simply the product of mortal machination in the face of divine absence. On the contrary, it involves the gods themselves, and implies their complicity and assent.

\section{Herodotus and tragedy}

Why, then, did Herodotus resort to an explanation of straightforward mortal trickery in the Phye episode, evoking the deceit of Peisistratus's theatrical first arrival, wounded and with wounded mules, into Athens' marketplace (1.59)? First, the historian drew upon the established repertoire of a good storyteller, stressing Peisistratus' trickster character by alluding to his capacity for deceiving others, even the clever Athenians! His scepticism towards Phye's status thus reinforces Herodotus' historiographical agenda. One might even suggest that our written text derives from an oral performance in front of an Athenian audience, and imagine a smiling Herodotus teasing his listeners with the suggestion that they might have been foolish enough to be deceived by Peisistratus (or, worse perhaps, that barbarians in earlier times were far cleverer than the Athenians themselves!). ${ }^{21}$ The passage may be compared to 5.97.2, where he "drily states that it was easier to deceive three myriads of Athenian than one Spartan". ${ }^{22}$ In the Pallene episode, we may note that Peisistratus immedi-

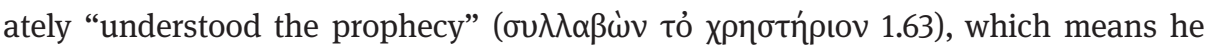
easily put together the enigmatic verses and his present circumstances (sun-labein),

selon des critères très stricts, ces enfants sont dépouillées de leurs attaches terrestres et acquièrent un corps divin au cours d'une consécration ... assez semblable aux rituels célébrés lors de l'installation d'une statue divine dans un temple ou un sanctuaire. Le corps de la petite fille vire au rouge, disent les brahmanes, lorsqu'elle s'assied sur le trône aux lions ...”

20 See Koch Piettre 2001, 215ff. By the word "deception" here I do not mean mimetic representation but that first, in Archaic texts an epiphanic god does not appear in his own form, although s/he may appear radiant or terrifying; see Vernant 1986a and Loraux 1991; second, s/he quickly disappears; third, often s/he plays a trick on the onlooker or helps a trickster. On trickery in a military context see also Polyaenus 1.41.1, and Petridou 2015, ch. 2.

21 See above n. 7. Herodotus' lectures at Athens are mentioned by Euseb. Chronic Arm. 83, for the year 445/4 or 446/45; see also Diyllos FGrH 73 F 3. On orality in Herodotus see Thomas 1992, 125-6, Thomas 1993 and Thomas 2000, 20, ch. 8; Murray 2001, 30 and Slings 2002. On the narrative form of anecdotes see Flory 1987, ch. 2 (although the author focuses on a written genre derived from orality).

22 Shimron 1989, 69. According to Moles 2002, 58, "Throughout, Athenian credulity and inability to read signs contrast, implicitly, with Spartan cleverness". Thucydides was well aware of Athenian viewers' credulity: see $3.38 .4-7$. 
in order to devise a cunning stratagem. The second return story thus also fits the trickster character type.

Second, Herodotus may actually have been chocked by the story. According to K. A. Raaflaub, he seems to have been well acquainted with "the intellectual koine in late fifth-century Hellas"; in matters of religion, rationality tends to "belief in a divinely ordained and maintained balance in nature", in which divine will is attributed with moral and reasonable motives. ${ }^{23}$ We cannot, then, dismiss the possibility that in Herodotus' view the idea of divine complicity in human trickery would have been irrational and scandalous: a god is a perfect being, who cannot assist dishonest propaganda. In this sense, the prophecy of the Pallene anecdote conformed better to a rational notion of divine providence, alluding merely to the opportunity offered by military action. Moreover, in matters of politics Herodotus condemned tyranny. The city of Athens seems to lie at the heart of his work due to the Athenians' role as saviors of Greek liberty during the Persian war. Yet the same city turned enslaver of other Greeks "and became the polis tyrannos against which the Spartans eventually rallied with their own battle cry of freedom” (Thuc. 2.8). ${ }^{24}$ Could such a protoThucydidean attitude have inspired Herodotus' criticism of the Athenians' credulity and fickleness?

Third, Herodotus stayed in Athens during the time of Pericles and Sophocles and seems to have moved in their circles, so we may suppose he was well acquainted with the problems and evolution of tragic poetry and stage performance; he must certainly have joined the audience at tragic festivals. ${ }^{25}$ Perhaps he saw one or two decades later some crane scenes with $\theta$ coì $\alpha$ đò $\mu \eta \chi \alpha v \tilde{n}$, , which Aristophanes began parodying a year after Herodotus' death in his comedies Clouds (423) and Peace (421). The crane was also necessary for the role played by Oceanus in (pseudo?) Aischylus' Prometheus, and for many plays by Euripides, Medea, Andromache, Electra, Hercules furens and Orestes (possibly also Hippolytus, Suppliants, Ion, Iphigenia in Tauris, Helen and Bacchae). It seems unnecessary, however, for the epiphany of Heracles in Sophocles' Philoctetes. ${ }^{26}$ Aristoteles condemned this alogon in his Poetics (1454 a-b, cf. 1460 a 29):

23 Raaflaub 2002, 154. 158. 160 (with further bibliography).

24 Raaflaub 2002, 167. See also 165-179; Moles 2002, 36 about "Herodotus' typology of tyranny"; Lewis 2004 about the evolution of ideas about tyranny constructed by historians.

25 See Plut. Mor. 785B (an epigram written by Sophocles for Herodotus) and fr. 79 Diehl Anth. Lyr. Graec. Sophocles is said to have paraphrased the words of Solon in Herodotus (Trach. 1-3): see Saïd 2002, 117. 146 and Chiasson 2003. Vernant 1981 sees close links between Sophoclean and Herodotean túpavvol. Osborne 2002, 514 states that "Herodotus' account surely reflects the Athenians' own attitudes in the middle of the fifth century".

26 On the deus ex machina see Mueller 1910, Kleinknecht 1937, Longo 1963, Mastronarde 1990, Newiger 1990, Pucci 1994, Easterling 1993 and Sourvinou-Inwood 2003a, part 3, ch. 4, "Walking among Mortals? Modalities of Divine Appearance in Aeschylus, Sophocles, and Euripides”. 
The 'god in the car' should only be used to explain what lies outside the play, either what happened earlier and is therefore beyond knowledge, or what happens later and needs to be foretold in a proclamation. For we ascribe to the gods the power of seeing everything. There must, however, be nothing inexplicable in the incidents, or, if there is, it must lie outside the tragedy. ${ }^{27}$

Is it significant that such rationalization of tragic epiphany corresponds so closely to the works of Herodotus' contemporary (and alleged friend) Sophocles? We know of epiphanies in at least Sophoclean tragedies: in addition to Philoctetes, there is the initial appearance of Athena in Ajax, and the disappearance of the blind beggarking on the steps of a leading anonymous god in Oedipus Coloneus. Each of these Sophoclean epiphanies is well-grounded in the tragic plot, avoids spectacular effects, and would not flout Aristotle's dictum. Oedipus' supernatural death happens offstage, foretold by many omens and oracles, and the response of Theseus (who is the episode's only eye-witness), echoes traditional avoidance of the gods' shining ap-

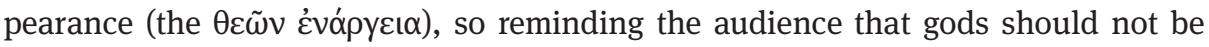
seen directly by men. They are seen, but (because of the due respect) they should

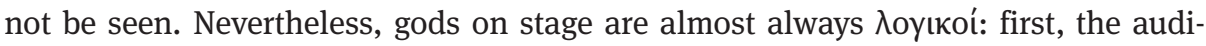
ence is encouraged to understand the plot from a quasi-divine point of view, in order to know things of which internal characters are supposed to be unaware; second, the audience is aware of the god's disguise (that is, their fictional status for spectators). Within the frame of tragic performance, gods on stage are neither masked gods, nor epiphanic gods, but plain godlike masks.

Within certain ritual contexts, men were allowed to approach the gods, to see them in the guise of their ritually animated images, whether in the temple cella, carried in procession, displayed in mystic spectacles or hosted by some private person, such as Sophocles' reception of Asclepius in his house. ${ }^{28}$ Festivals in honor of Dionysus belong to these circumstances. ${ }^{29}$ Yet Dionysus was a mask-a mask-god. ${ }^{30}$ The mask-god is not a masked god, nor a disguised god, for the Greeks thought this mask to be the true visible face of the invisible god, providing access to his invisibility. The

27 Transl. Loeb Classical Library. See also Plat. Cra. 425d on "tragic poets, who, when they are in a dilemma, have recourse to the introduction of gods on machines".

28 On ritual epiphanies see Weniger 1923-1924; on images in mystic or ritual drama see Gordon 1979 and Nielsen 2000; on cult statues see Gladigow 1985-1986 and 1990, Scheer 2000 and Bettinetti 2001; on viewing as ritual performance see Tanner 2006, 45-48. On Sophocles and Asclepius see Vita 11 and Etym. Magn. s.v. $\Delta \varepsilon \xi^{\prime}\left(\omega v\right.$; cf. IG II $^{2}, 1252$, 1253, though Connolly 1998, 20 argues that it is unlikely that the poet received heroic honors before the 330s and dismisses the story of Asklepius' xenia as "Hellenistic [or even later] fabrication". On hospitality towards the gods see in general Flückiger-Guggenheim 1984; on $\theta \varepsilon 0 \xi \varepsilon v i ́ \alpha$ see Bettinetti 2001, ch. 7.

29 On this important point see Seaford 1981; Friedrich 1985 and Friedrich 1996; Easterling 1988 and Easterling 1997; Winkler and Zeitlin 1989 (esp. Longo, Winkler and Goldhill); Henrichs 1990; Mikalson 1991; Lonsdale 1993, 6-8 and Sourvinou-Inwood 2003a. On scenes of cult practice onstage, see Jouanna 1992.

30 See e.g. Frontisi-Ducroux 1991 and Carpenter and Faraone 1993: Dionysus was not a masked god, but a "mask-god". 
mask of Dionysus is not a representation, but a self-presentation-an epiphany. ${ }^{31}$ In this sense it is ambiguous, tricky and deceptive by its very nature. ${ }^{32}$ The god is really seen, but how can people know when the god is actually present in his mask, or when he might already be hidden in the onlooker's own features? ${ }^{33}$ Thus, as in the Bacchae, he may appear first as a god facing the audience, a 'real' god for this audience during the time of the ritual plot, no less god than other gods in procession; second, as an actor on stage, conversing with other actors; third, as a fictive character interacting with other characters; and fourth, as a mask-god, a lying god per se. We find here a paradox, for while staged gods were pleasant and impressive, causing fear and pity, they were at the same time not true gods but mere imitations; therefore the god who was most lifelike was also the most deceptive (unless he was the lying god himself). ${ }^{34}$

Of course, masks may facilitate fictional performances even in ritual circumstances, when for instance the priest of Demeter Kidaria at Pheneos in Arcadia, during the Greater Mysteries, puts on the mask of the goddess he takes from a hollow stone, and "for some reason or other beats the Folk Underground". ${ }^{35}$ Yet for the Greek viewer this masked priest is Demeter Kidaria herself, the beating is good for him, he in turn also becomes a character in the ritual plot. Although the scenario is fictive, there is no escape from the relationship it generates between god and viewer. As Victor Turner and Michel Leiris have argued, possession is theatrical and performative, yet for the possessed and for his viewer, it is also a very 'real' experience. ${ }^{36}$ In the case of possession the actors present the god's true (although temporary) features; the god 'really' speaks through their mouth and acts through their gesture.

In the Athenian theatre, however, something else happens, in spite of the rapturous music and the citizens' eager participation, in spite of the expression the chorus gives to the emotional dynamics of the plot, in spite of the fact that tragedy and comedy coincide with civic duty and ritual performance in the context of Dionysus' cult. ${ }^{37}$ Citizens and perhaps $\theta \varepsilon \omega \rho o i$ (the cities' embassies, who witness the festivals and in some way diffuse their blessings-if these blessings are intended for more than one

31 On masks from an anthropological viewpoint see Lévi-Strauss 1979 and 1989, 177-184 and Bettini 1991.

32 Vernant 1986b.

33 Note the mirror in the temple of the Mistress at Lycosoura (Paus. 8.38.7), which, instead of the viewer's face, reflects the cult statue, and the interplay of mask and mirror in the fresco of the Villa of the Mysteries at Pompeii (on which see Veyne 1998, 104-108 and Sauron 1998, 138-140). 34 Arist. Poet. 1452a, 1453b.

35 Paus. 8.15.3. On the mysteries and ritual drama see Nielsen 2000.

36 Turner 1982; Leiris 1989.

37 See e.g. Goldhill 1997 on "the audience as city" during the Great Dionysia at Athens, and Calame 2001, 118: "les acteurs et les choreutes [...] attique[s] sont engagés aussi bien dans l'action jouée sur la scène que dans le rituel consacré à Dionysos en son sanctuaire du théâtre." See also more broadly Turner 1986. 
imperialist state or civic body!) become $\theta \varepsilon \alpha \tau \alpha$ í, mere observers, passive spectators. ${ }^{38}$ The tragic or comic plot has no direct influence on the viewer's own fate, but only on his mental knowledge, ideas and emotions. Catharsis on this level is not experienced as ritually 'real', but in a more abstract, metaphorical sense. If viewers desire the fic-

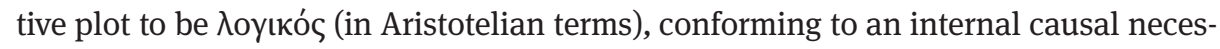
sity, then they are no longer within the register of their own lives, in which ritual artifacts have a direct impact (through blessing or healing, for example) upon their destiny; they are outside the plot, and none of the characters' utterances need express their immediate concerns. Instead, the audience is concerned with the author's purpose and design, communicated through the words spoken by the dramatis personae; the gods themselves are reduced to tools within that implicit dialogue between author and audience (a dialogue which may become explicit in the parabasis of the Athenian comedy). Their epiphany as dei ex machina may seem to establish a third level of enunciation, in which divine characters talk not only to the mythical characters from the theologeion, but also directly to the audience, explaining the context of the plot or the final destiny of the characters. Yet, like the parabasis, this is only another fictive means of giving voice to the concealed author/scriptor/narrator. ${ }^{39}$ Real gods, real epiphanic experiences, like Theseus' terrific glimpse in the Oedipus Coloneus, are ő̉oy $\alpha^{40}$ One sees what cannot be seen; one hears what cannot be heard; gods are here but not here. Yet the hearing and seeing rest on this very paradox.

In her influential book Tragedy and Athenian Religion, Christiane Sourvinou-Inwood demonstrated that for the Athenian audiences tragic spectacle remained religiously significant, offering a highly theological experience even in Euripides' more sceptical drama. I do not contest her detailed analysis, but on the contrary argue that the growing influence of mimesis elicited a new religious attitude in the fifth century, in which it became possible for the general populus to question religious tradition and seek the best way of depicting their gods. While Aeschylus' Erinyes could still frighten the Athenians, as in a 'real' epiphanic appearance, Prometheus (clearly a later tragedy) constantly calls his divine or mythical audience (and, implicitly, his human spectators) to gaze at him, to feel sorry for him, to condemn his suffering: spectacle has replaced epiphany. ${ }^{41}$

38 Thuc. 3.38: the Athenians are described by the politician Cleon as "spectators of speeches". About their "competence", see Revermann 2006. For a parallel shift in the viewing of fifth century BC art, see Elsner 2006.

39 On "double enunciation" in theatre, see for instance Ubersfeld 1993, $129 \mathrm{ff}$.

40 In the tragic narrative of Oedipus Coloneus (1650 ff.), choral songs and messenger speeches are employed to represent serious non-mimetic ritual practice that has taken place offstage. Aeschylus' Choephoroi and Electra acted onstage.

41 See PV 69, 92ff., 119, 140, 143, etc. Unfortunately Sourvinou-Inwood 2003a does not include the Prometheus in her analysis, though I certainly do not want to refute Sourvinou-Inwood's conclusion that "Far from diluting or subverting the religious content of tragedy, Euripidean tragedies with a deity ex machina gave it a new and powerful injection of religious significance and resonance” 
In $\theta \varepsilon o i ̀$ órò $\mu \eta \chi \alpha v \tilde{\Upsilon} \varsigma$ scenes, then, Herodotus could have experienced the ambiguity of Dionysus' mask as a progressive change from ritual and civic participation to mimetic spectacle, in such a way that in spite of the impressive phenomenological effect of such spectacle, he was distanced from the sense of social commitment and enthusiasm men dressed as gods might have inspired to their worshippers during the time of Peisistratus. Moreover, although tragic festivals preserved their cultic value until the end of the fifth century (as Sourvinou-Inwood convincingly argues), we must not forget that Herodotus was not Athenian. In performance theory, spectators are part of the spectacle, but ancient festivals also involved passive spectators because they attracted many visitors from other cities, who sometimes came not to share in the religious and Panhellenic event, but as mere spectators of an alien city's pride and vanity. ${ }^{42}$

\section{Demetrios Poliorcetes, theatre, and Hellenistic epiphaneia}

The paradoxal perception of epiphany-a seeing suppressing all perception, as in

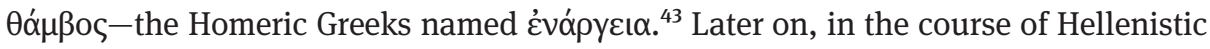

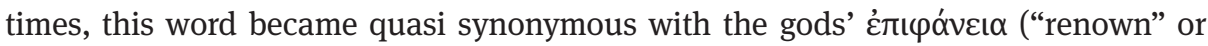
"appearance"). Now it seems, at first glance, that the appearance of gods on stage

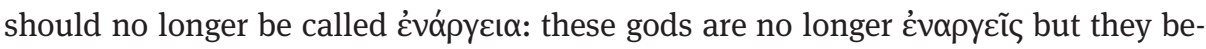

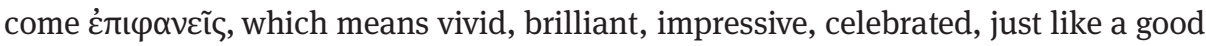
actor. ${ }^{44}$ The mimetic representation of religion in Greek drama generated a different

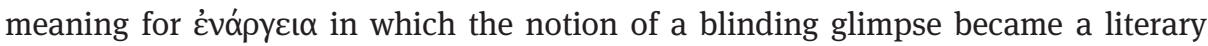
concept associated with imaginative visualization-a process that has been well investigated in recent scholarship. ${ }^{45}$ Appearance-whether in mimetic drama or illusionistic painting, sculpture and written descriptions-thus offered a higher form of experiencing reality. Fernand Robert has stressed, for instance, the new Hellenistic

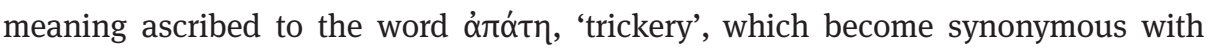
'pleasure', 'enjoyment', voluptas. ${ }^{46}$

(499). With the development of mimesis the religious significance of drama changed but did not disappear. See also Sourvinou-Inwood 1997.

42 See e.g. Hall 1989.

43 The Homeric word ह̇vapyńs means 'striking' or 'evident'; its use always implies the divine nature of an apparition has been recognized by the viewer, even if the apparition has already disappeared. The point is not perception, but recognition: Koch Piettre 1999.

44 See Koch Piettre 1996, ch. III.8-9.1-4.

45 See Zanker 1981; Ginzburg 1989; Calame 1991; Pernot and Lévy 1997; Koch Piettre 1999 and Platt 2004.

46 Robert 1960. The probable use of the word by Gorgias fr. 23, 1. 3 D.-K., quoted by Athenaeus 5

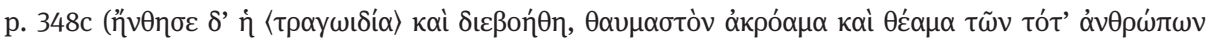


We do not want to insist on the obvious comparison between Peisistratus' arrival in Athens in 565 BC and the well-known entry of Demetrius Poliorcetes about two hundred and fifty years later (in 307), as related by Plutarch (Demetrius 10-13) and Athenaeus (6.253a-254b). ${ }^{47}$ In this later example, the tools customarily employed for constructing godlike men enabled the creation of a seductive illusion that surpassed reality (that is to say, ritually constructed gods). So it happened that the assimilation of a godlike man to a god could sometimes be so complete that all the ritual privilege of gods actually passed to men: godlike humans remained human, but they were honored like gods. ${ }^{48}$ Demetrius (who claimed he would re-establish democracy and restore Greece to liberty) and his father Antigonus were honored by the Athenians as $\Theta \varepsilon o i \quad \Sigma \omega \tau \tilde{\eta} \rho \varepsilon \varsigma$; an annual priesthood was established in their honor; Demetrius' name was uttered before each public act, instead of the name of the king-archon; the faces of father and son were woven among those of the other gods on Athena's peplos. The very place where Demetrius dismounted was provided with an altar and consecrated to Demetrios Katabaites, like places marked by Zeus' thunderbolt: the ruler is thus divine per se, while Peisistratus needed a divine

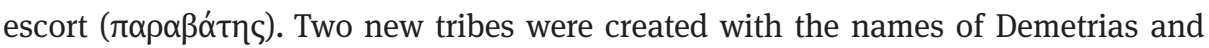
Antigonis; Athenians were ordered to welcome Demetrius with the same hospitality gifts as for Demeter and Dionysus; the name of the month Mounychion was changed to Demetrion; the first and last day of each month became Demetrias; the festival of Dionysus was devoted to Demetrius and called Demetria. Thus Herodian could describe him as "imitating Dionysus in every way, even wearing a crown of ivy instead of the Macedonian hat or the diadem, and carrying the thyrsus instead of a sceptre". ${ }^{49}$ Moreover, any messengers the Athenians sent to Antigonus or Demetrius were to be called $\theta \varepsilon \omega \rho o$, 'ambassadors to the gods'. Even an oracle was sought from Demetrius, about shields the Athenians intended to consecrate to Apollo at Delphi. It was in such a context, as we may read in Athenaeus, that the Athenians could sing their ithyphallic hymn at Demetrius' triumphal entry and praise him with the words:

The other gods are either far away, or deaf, or do not exist, or they pay us no attention;

But you we see here,

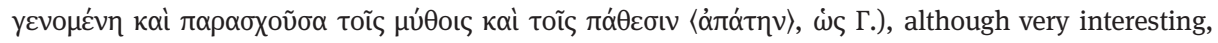
does not support this meaning.

47 This parallel has been drawn in an important paper by Chaniotis 1997, esp. 225, 232ff., 241- 244 on Demetrius Poliorcetes; see also Herodian 1.3.3, with Chaniotis 1997, 241 n. 109.

48 On parallel practice in Roman Imperial cult see e. g. Gradel 2002.

49 1.3.3, transl. Echols 1961. 
not made of wood or stone, but real.

To you, then, we pray....

In spite of a quick reversal of opinion among the Athenians, and in spite of the scandalized mockery of Plutarch and Athenaeus, such immoderate praise need not be understood as straightforward blandishment. In the context of a shift from democracy to monarchy, and of the Athenians' need to justify their new political order, it can be understood as genuine cultic behavior. Antigonus and his son claimed to share "a wonderful eagerness to give freedom to all Greece", and restored their laws to the Athenians, fourteen years after they had lost their democratic form of government. ${ }^{51}$ Over the course of time, liberty had become the most sacred cause and symbol of Panhellenic identity, and it was in many ways inevitable that the Greeks would honor with cult and symbolic gesture what they had lost in fact. Athens, moreover played the role of liberty's conservator, maintaining its spirit at least in the frankness-or parrhēsia-of some philosophers, especially those of the Cynic, Stoic or Epicurean schools..$^{52}$ If the observations of Elpidius Pax remain correct, then the first

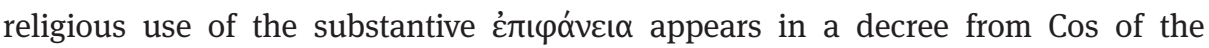
year 278 BC, praising the Delphic god Apollo for his miraculous defence of Greek liberty against the Gallic invasion. ${ }^{53} \sum \omega \tau \tilde{\eta} \rho \varepsilon \varsigma$-rescuers and liberators, men or gods-

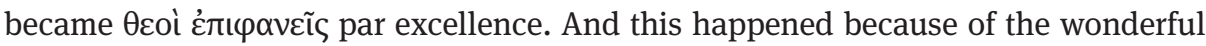
renown that crowned with glory all kinds of healing and divinely favored signs,

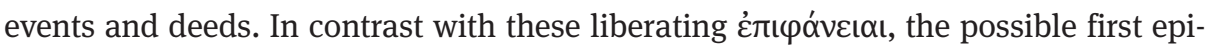
graphic appearance of an epiphanic god or demi-god-in fifth-century inscription from the Cerameicus in honor of the dead at the Athenian defeat near Coroneia (447 BC), caused no liberation, but harm and misfortune. ${ }^{54}$

In the Hellenistic period (and its reception in later Second Sophistic texts), godlike appearance becomes commensurate with full godhead. Demetrius projects ì $\rho \omega$ -

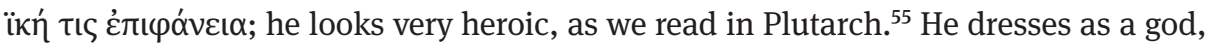

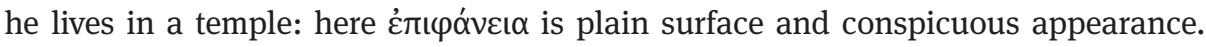
But nevertheless, it is a salvific, sanctified appearance. Ruler cult, after all, was not the product of mere flattery and adulation, but was thought of as genuine reli-

50 Ath. 6.253e, transl. Loeb Classical Library. Three years later, Demetrius returned to Athens and reportedly took up residence in the Parthenon, which he defiled by his life of debauchery (Plut. Demetr. 23 -24). On deification see e.g. Scott 1928; Manni 1952, 24-27; Habicht 1970, 50 - 55, on Demetrius Préaux 1978, 238 -271, esp. 246-248; Connor 1989, 19ff.; Green 1990, ch. 22, and on Roman emperor worship Gradel 2002 and Cancik and Hitzl 2003. How far are these tales authentic, rather than later historiographical conventions conforming to the rhetoric of tyranny? It seems at least that they are often borrowed from Hellenistic sources: see below on Duris.

51 Plut. Demetr. 8.

52 See e.g. Diogenes the Cynic, and Philodemus' De libertate dicendi, in Konstan's edition (1998).

53 Syll. $^{3}$ 398; see Pax 1962, 842- 43.

54 Peek 1955, 1 no 17; see Pritchett 1979, 26.

55 Plut. Demetr. 2.2. 
gious practice. Traditional anthropomorphism paved the way for people to select and highlight epiphanic details from religious ritual such as processions (associated with divine adventus, or $\left.\varepsilon \pi ı \delta \eta \mu^{\prime} \alpha\right)$, applying these aspects in spectacular style to the cultic self-presentation of kings and generals (e.g. docking with a fleet or celebrating their victories). ${ }^{56}$

\section{"Tragic" history}

Hellenistic historians are countless, especially at the local level. Among them we encounter a few busily gathering 'epiphanies' (that is to say miraculous events) such as the Rhodian Timachidas. ${ }^{57}$ Among Plutarch's sources for the Life of Demetrius, Diodorus' history of related events for the years 301-283 is no longer extant. We are therefore reliant upon Plutarch's references to Hellenistic authors such as Hieronymus of Cardia, Duris of Samos, Phylarchus and Philochorus of Athens. Athenaeus quotes the ithyphallic hymn preserved by Duris of Samos, who also seems to be the most important source for Plutarch's biography. ${ }^{58}$

Scholars are rather critical of this Duris. ${ }^{59}$ His guiding principle is that of mimesis, as on stage, so that the reader may experience the events related, as if he were witnessing them himself. Such historiography rejects rhetoric of the Isocratic mould and instead looks to Thucydides' description of the plague in Athens and even Homer's narrative style in the Iliad as models. It thus aspires to a kind of 'real-

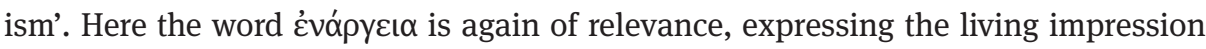
created by a highly realistic description, the means by which words place events before one's eyes and thus stimulate the mind. We may note in particular the rhetorical

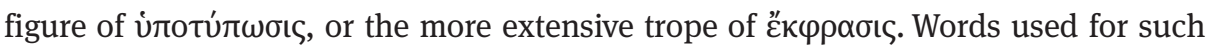

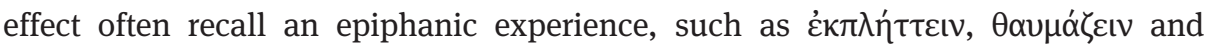
ó $\psi \varsigma^{60}$.

56 See e.g. Cancik and Hitzl 2003. According to Price 1984, 82ff. and Gradel 2002, deity should be defined by honors rather than ontological status. Yet in the Hellenistic period, divine honors may have changed the perceived status of some, but there were also ontological reasons for the change: first, socio-political influence, lavishness and court magnificence suggested a higher nature; second, gods were not thought of as mere "powers", but as seriously anthropomorphic, in which case a beautiful man or woman could be considered godlike; third, in Hellenistic philosophy, the correct idea of reality is more important than reality itself; for Epicurus the gods existed far from the human realm, yet true likenesses (such as statues) and mental images were enough to realize an ideal of (quasi?) divine happiness for men. See below, n. 71, and Koch Piettre 2005a and 2005c.

57 FGrH 532; see Higbie 2003 and Koch Piettre 2005b.

58 Ath. 6.253d-f = FGrH 76 F 13; the relevant fragments on Demetrius Poliorcetes are F 13, 14, 15. 59 Jacoby 1956: a mere "rhetor"; but for Strasburger 1975, 78 ff. (Studien: esp. 996), Hellenistic historiography concerns itself not only with style but with 'actual' experience.

60 Above n. 43. 
Plutarch's historiographical style in the Lives is highly indebted to the Hellenistic tradition of Duris. How does he describe the epiphanic appearance of Demetrius? The ruler is continually characterized in terms of theatrical performance, with frequent comparisons to characters familiar from tragic drama. The reader is often invited to gaze upon the events related as if sitting in a theatre; while the text refers to the crowds viewing the godlike general, Demetrius' appearance is described from the point of view of the crowd. ${ }^{61}$ We are invited to visualize the imposing arrival of Demetrius' vessel into Athens' harbor (8.4); his appearance on the logeion in the theatre of Dionysus before the eyes of the terrified Athenians $(34.3-4) ;{ }^{62}$ or the solemn reception of his ashes by his son Antigonus operating with the complete military fleet $(53.1-3) .^{63}$ At the end of his carrier, when Demetrius is forced to fly like an outlaw, Plutarch (perhaps following Duris) quotes Euripides in order to compare the fallen leader with a god in a disguised epiphany-a god in the shape of a man (45.3). ${ }^{64}$

Of course, we cannot be sure that the theatrical elements of Plutarch's Life of Demetrius are derived from Duris. We may argue that the parallel Life of Antony is equally full of theatrical language and description (esp. 9.6-8, 24.4-5, 26). And yet Antonius' political strategy was clearly an imitatio (diui) Alexandri, a very Hellenistic dream that was not without an element of Realpolitik. Like Alexander, Cleopatra's father Ptolemy XII Auletes was called Neos Dionysos, and proudly exhibited his royal

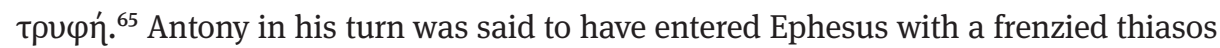
of costumed Bacchai, Saturoi and Panes (Ant. 24). The ideology of kingship adopted by both Antony and Cleopatra thus drew upon a shared celebration of $\tau \rho v \varphi \eta$, theatre, and Dionysiac mise en scène. ${ }^{66}$

The godlike Hellenistic king Demetrius thus differs from Herodotus' Peisistratus in two important aspects. First, Demetrius is the focus of cultic honors as to both god and king, rather than traditional anthropomorphic deities; he is not only a favourite of the gods, but he wants to be considered as a visible god himself (like the disguided

61 Plut. Demetr. 8.4, 16.3, 17.2-5, 18.3, 21.4, 25.6, 34.3, 41.3-4, 44.6, 45.2-3, 53.1-3.

62 See also the incredible luxury of his costume, Ath. 12.535e-36a = FGrH 76 F 14.

63 Cf. FGrH76 F 70 = Plut. Alc. 32: Plutarch's (or Duris') description of Alcibiades' return seems anachronistic, although Alcibiades' taste for costume or the Eleusinian mysteries (Plut. Alc. 19-20 and 34.3-7), where priests impersonated gods (Chaniotis 1997, 248), suggests other similarities to Demetrius (Plut. Demetr. 26.1-3); Duris was perhaps inspired by the return of Demetrius' ashes, which it is not unacceptable to suppose he could have witnessed himself. See Pédech 1989, 359 and 377 ("La ressemblance des deux passages est frappante et l'attribution du second à Duris ne fait aucun doute"), or Chaniotis 1997, 244.

64 Here Plutarch does not quote Duris, but on the latter's taste for theatricality (costumes, imitation of actors, mechanical devices), esp. in his depiction of Demetrius, see Mastrocinque 1979; Marasco 1981; Torraca 1988; Pédech 1989, 342-44. 354-62. 378-86; and Chaniotis 1997, 225, 233, $244 \mathrm{ff}$.

65 See also the festival of Daphne organized by Antiochus IV (Diod. Sic. 31.16, Polyb. 30.25, Ath. 5.194c-195f and 439b-d).

66 See also Cic. Phil. 2.63, 84. As Verity Platt kindly warns me, this should not prevent us from studying the Second Sophistic use of such descriptions in their own context; on Plutarch as an historian, see Pelling 2002. 
Phye). Second, instead of performative trickery he uses actual machinery; instead of cultic traditions he employs mechanical stage devices, in order to present his subjects with impressive spectacles. Even war becomes a kind of performance art under his rule. His victories are achieved through artful $\tau \dot{\varepsilon} \chi v \eta$, and he has expertise in the art of painting no less than in that of siege machinery (22.2-3, 20.1-4). Tyranny involved the gods' visible assistance; kingship, however, replaces it.

But did the Hellenistic historians maintain a belief in traditional religion? What was Duris' opinion about the gods? To what extent might Plutarch have been influenced by his source? In his biography, Plutarch condemns the Athenian cult of Demetrius as mere flattery, but he does not condemn Demetrius himself, highlighting his pious courtesy $(6.4,17.1,30.2)$. Yet Plutarch in his turn looks to 'real' gods, who must trounce in some way the novelties he rejects. 'Real' (traditional) gods thus appear by means of signs and omens, e.g. punishing the Athenians' rash impiety through various portents, which Plutarch quotes in detail (12.2-4). In contrast to Demetrius's mimetic, anthropomorphized epiphany, signs of divine justice are miracu-

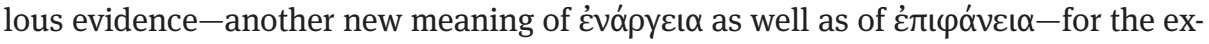
istence and divine authority of the invisible gods.

We find Hellenistic evidence for such an attitude in the traces of Duris' pupil and follower Phylarchus, who was the source of both Athenaeus' account of Peisistratus' trickery and Plutarch's lives of the Spartan kings Agis and Cleomenes. ${ }^{67}$ Plutarch relates, for example, that Agis' friends took advantage of oracles as a pretext for a return to the laws of Lycurgus; when these same friends happened to observe a shooting star, they claimed it was a sign that king Leonidas (who opposed the reform) was guilty of an offence against the gods, and so dethroned him (Agis 9.1-4, 11.4-9). Here we find political trickery comparable with Peisistratus' use of Phye: yet gods are alleged to manifest themselves through oracles and heavenly signs, not in an epiphanic mise en scène. In another fragment ( $F$ 78), Phylarchus explains that the Egyptian gods Apis and Osiris were two oxen, led by Dionysus from India to the

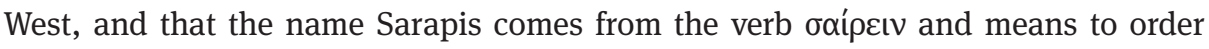
and clean the universe. This looks as if it were mere rationalization, yet in $\mathrm{F} 45$, the same Phylarchus relates that the inhabitants of Sybaris, having traitorously killed ambassadors from Croton, received by signs and wonders a show of divinity's wrath: magistrates dreamed that Hera would vomit her gall in the marketplace, and a spring of blood burst forth in the temple. ${ }^{68}$ This time, it is the coincidence between to signs,

67 Ath. 13.609c refers to Phylarchus: "the woman who restored Peisistratus to supreme power" had

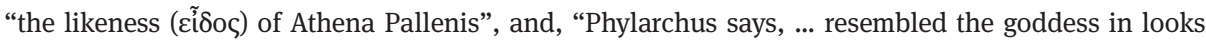
( Phylarchus as a source for Plutarch's Life of Agis, see e. g. Pédech 1989, 403. 428-29. 455. 457-58. Scholars interpret Phylarchus' religious attitude in various ways: see Africa 1960 (mere rationalism); Marasco 1980 (a genuine faith) and Pédech 1989, 471-75 (mythography without any religious feeling). 68 See Pédech 1984, 472-74. 
a dream and a supernatural phenomenon, that establishes a divine warning considered as obvious and credible by the historian.

\section{Conclusion}

From Peisistratus to Demetrius, under the influence of tragic drama, the utilization of epiphanic appearance in the staging of power shifted from ritual to spectacle. In response to the political exploitation of alleged supernatural signs, the general populus seems to have shifted from religious acceptance and constraint to plain emotion, fright and excitement on one hand, or moral and/or aesthetic judgement on the other. We may have already noted moral criticism in Herodotus' account of Peisistratus and Phye. But in this passage Herodotus was not concerned with religion but with a rationalizing approach to politics. In contrast, the 'tragic' historians were concerned with both evaluating religious practices and engaging their readers' sensibility to the divine. In this way, they were responding to epiphany's status as an important tool within the Hellenistic religio-political system.

By criticizing the political use and abuse of religion, Hellenistic authors such as Douris (behind Plutarch) and Phylarchus may have demonstrated the same impulse to religious reform that we find in contemporary Athens or Sparta. By rationalizing the evidence, they try to select the most useful, moral, striking and convincing forms of divine appearance. Spectators are sceptical fellows, fond of signs and epiphanies, but not of every sign and epiphany-only of the most self-evident or 'real' ones. In the same period as Epicurus, then, Duris and Phylarchus also try to save the reliability of lifelike images, of eidola which were not yet called idols. ${ }^{69}$

69 On Epicurean ideas about mental perception of gods see esp. Ep. Men. 123, and [Demetrio Lacone], [La forma del dio], in Santoro 2000. For Epicureans, a godlike image could recall the true form of the gods (everlasting life without any disturbance), which had been lost or distorted by humans after their primitive experience of epiphany (see Lucr., $5.1169 \mathrm{ff}$.). Through the correct impression of imagination ( $\left.\varphi \alpha v \tau \alpha \sigma^{\prime} \alpha\right)$, such forms could support human happiness. This idea has a materialist foundation in the theory of vision. Note that Duris' brother Lynceus stayed with him at Athens at the school of Theophrastus; the hedonistic tone of his work (FHG II 466-88, esp. 466 n. 1) may suggest an acquaintance with the Epicurean school. On Epicurus' attitudes to gods see Koch Piettre 2005a, ch. 2. 4.5 and 7, with extensive bibliography; on epiphanies in Epicurus and among Epicureans see also the final chapter of Koch Piettre 1996, Koch Piettre 1998 and Mackey 2006. 


\section{Bibliography}

Africa, T. W. 1960. "Phylarchus and the Gods. The Religious Views of a Hellenistic Historian", Phoenix 14. 222-227.

Back, F. C. 1883. De Graecorum caerimoniis in quibus homines deorum vice fungebantur. Berlin: Dissertation.

Bettini, M. (ed.) 1991. La Maschera, il doppio e il ritratto. Roma-Bari: Laterza.

Borgeaud, Ph. 1979. Recherches sur le dieu Pan. Rome-Genève: Droz.

Calame, C. 1991. "Quand dire c'est faire voir: l'évidence dans la rhétorique antique”, Études de lettres 4. 3-22.

Calame, C. 2001. "Quelques formes chorales chez Aristophane: adresses aux dieux, mimésis dramatique et 'performance' musicale." In Chanter les dieux. Musique et religion dans l'Antiquité grecque et romaine, ed. P. Brulé and Ch. Vendries. Rennes: Presses Universitaires de Rennes. 115-140.

Cancik, H. 1990. "Epiphanie/Advent". In Handbuch religionswissenschaftlicher Grundbegriffe 2, ed. H. Cancik, B. Gladigow and M. Laubscher. Stuttgart: Kohlhammer. 290-296.

Cancik, H.; Hitzl, K. (ed.) 2003. Die Praxis der Herrscherverehrung in Rom und seinen Provinzen. Tübingen: Mohr Siebeck.

Carpenter, T. H.; Faraone, C.A. (ed.) 1993. Masks of Dionysus. Ithaca \& London: Cornell University Press.

Carrière, J. C. 1999. "Prodige, stratagèmes et oracle dans la prise de pouvoir par Pisistrate (Hérodote, I, 59-65)." In Pouvoir, divination, prédestination dans le monde antique, ed. É. Smadja and É. Gény. Institut des sciences et techniques de l'Antiquité: Presses Universitaires Franc-Comtoises. 13-32.

Cerfaux, L.; Tondriau, J. 1957. Un concurrent du christianisme. Le culte des souverains dans la civilisation gréco-romaine. Paris-Tournai: Desclée.

Chaniotis, A. 1997. "Theatricality beyond the Theatre. Staging Public Life in the Hellenistic World." In De la scène aux gradins. Théâtre et représentations dramatiques après Alexandre le Grand, ed. B. Le Guen. Pallas 47. 219-259.

Chiasson, C. C. 2003. "Herodotus' Use of Attic Tragedy in the Lydian 'logos', ClAnt 22.1. 5-35.

Connolly, A. 1998. "Was Sophocles Heroised as Dexion?", JHS 118. 1-21.

Connor, W. R. 1987. "Tribes, Festivals and Processions. Civic Ceremonial and Political Manipulation in Archaic Greece", JHS 107. 40-50.

Connor, W. R. 1989. "City Dionysia and Athenian Democracy”, C \& M 40. 7-32.

Deubner, L. 1966. Attische Feste. Hildesheim: Wissenschaftliche Buchgesellschaft [Berlin 1932'].

Easterling, P. E. 1988. "Tragedy and Ritual: 'Cry "Woe, woe”, but may the god prevail', Metis 3 [1991]. 87-109.

Easterling, P. E. 1993. "Gods on Stage in Greek Tragedy." In Religio graeco-romana: Festschrift für Walter Pötscher, ed. J. Dalfen et al. GB Suppl. V. Graz-Horn. 77-86.

Easterling, P. E. 1997. “A Show for Dionysus." In The Cambridge Companion to Greek Tragedy, ed. P.E. Easterling. Cambridge: Cambridge University Press. 151-177.

Echols, E. C. 1961. Herodian of Antioch's History of the Roman Empire. Berkeley \& Los Angeles: University of California Press.

Else, G. 1957. "The Origin of TPAГSIIIA", Hermes 85. 269-297.

Fehling, D. 1989. Herodotus and His 'Sources'. Citation, Invention, and Narrative Art, English transl. J. G. Howie. Liverpool: F. Cairns [1971 $]$.

Flory, S. 1987. The Archaic Smile of Herodotus. Detroit: Wayne State University Press.

Flückiger-Guggenheim, D. 1984. Göttliche Gäste. Die Einkehr von Göttern und Heroen in der griechischen Mythologie. Bern: Peter Lang. 
Fowler, R. 2003. "Herodotos and Athens." In Herodotus and his World, ed. P. Derow and R. Parker. Oxford: Oxford UP. 305-318.

Friedrich, R. 1985. "Drama and Ritual." In Themes in Drama V: Drama and Religion, ed. J. Redmond. Cambridge: Cambridge UP. 159-223.

Friedrich, R. 1996. "Everything to Do With Dionysos? (With the Answer of R. Seaford)." In Tragedy and the Tragic, ed. M.S. Silk. Oxford: Oxford UP. 25-38.

Frontisi-Ducroux, F. 1991. Le dieu-masque. Une figure du Dionysos d'Athènes. École Française de Rome: La Découverte.

Garland, R. 1992. Introducing New Gods. The Politics of Athenian Religion. London: Duckworth / Ithaca (N.Y.): Cornell UP.

Georgoudi, S. et al. (ed.) 2012. La raison des signes. Présages, rites, destin dans les sociétés de la Méditerranée ancienne. Leiden: Brill 2012.

Ginzburg, C. 1989. “Montrer et citer: la vérité dans l'Histoire”, Le Débat 56. 43-54.

Gladigow, B. 1985-1986. “Präsenz der Bilder, Präsenz der Götter”, Visible Religion 4-5. Approaches to iconology. 114-133.

Gladigow, B. 1990. "Epiphanie, Statuette, Kultbild. Griechische Gottesvorstellung im Wechsel von Kontext und Medium", Visible Religion 7. 98-121.

Gordon, R. L. 1996. Image and Value in the Graeco-Roman World: Studies on Mithraism and Religious Art. Aldershot-Brookfield: Variorum.

Gould, J. 1994. "Religion in Herodotus." In Greek Historiography, ed. S. Hornblower. Oxford: Oxford UP. 91-106.

Gradel, I. 2002. Emperor Worship and Roman Religion. Oxford: Clarendon Press.

Green, P. 1990. From Alexander to Actium: The Hellenistic Age. London: Thames \& Hudson.

Habicht, Chr. 1970. Gottmenschentum und griechische Städte [1956 $\left.{ }^{1}\right]$. München: Beck.

Harrison, T. 2000. Divinity and History. The Religion of Herodotus. Oxford: Clarendon Press.

Henrichs, A. 1990. "Between City and Country: Cultic Dimensions of Dionysos in Athens and Attica." In Cabinet of the Muses. Festschrift T. Rosenmeyer, ed. M. Griffith, D. J. Mastronarde. Atlanta, GA: Scholars Press. 255-277.

Henrichs, A. 1993. "Gods in Action: The Poetics of Divine Performance in the Hymns of Callimachus." In Callimachus, ed. M.A. Harder et al. Groningen: E. Forsten. 127-147.

Higbie, C. 2003. The Lindian Chronicle and the Greek Creation of their Past. Oxford-New York: Oxford UP.

How, W.W.; Wells, J. 1912. A Commentary on Herodotus, I.1. Oxford: Clarendon Press.

Jacoby, F. 1956. Abhandlungen zur griechischen Geschichtschreibung. Leiden: Bloch. 73-99 [Antike 2 (1926) 1-29].

Jouanna, J. 1992. "Libations et sacrifices dans la tragédie grecque”, REG 105. 406-434.

Kiechle, F.K. 1970. "Götterdarstellungen durch Menschen in den altmediterraneischen Religionen", Historia 19. 259- 271.

Kleinknecht, H. 1937. "Zur Parodie des Gottmenschentums bei Aristophanes”, ARW 34. 294-313.

Koch Piettre, R. 1996. "Le corps des dieux dans les épiphanies divines en Grèce ancienne." Paris: doctorate thesis, Paris: EPHE.

Koch Piettre, R. 1998. "La proscynèse de Colotès: une lecture de Plutarque, Moralia 1117 b-f", Lalies 18. 185-202.

Koch Piettre, R. 1999. "Les dieux crèvent les yeux: l'enargeia dans la représentation du divin”, Ateliers 21. La transmission de l'image dans l'Antiquité: Université Charles-de-Gaulle-Lille 3. $11-21$.

Koch Piettre, R. 2001. “Images et perception de la présence divine en Grèce ancienne”, MEFRA 113/1. 211-224.

Koch Piettre, R. 2005a. Comment peut-on être dieu? La secte d'Épicure. Paris: Belin. 
Koch Piettre, R. 2005b. "La Chronique de Lindos, ou comment accommoder les restes pour écrire l'Histoire." In Les objets de la mémoire, ed. Ph. Borgeaud and Y. Volokhine. Studia Religiosa Helvetica 2004/05. Bern-Berlin: Peter Lang. 95-121.

Koch Piettre, R. 2005c. "'Il faut faire les statues des dieux joyeuses et souriantes': Diogène d'ÆEnoanda (fragment 19 Smith) en réformateur de la religion olympienne dans la Grèce d'époque romaine." In L'idole dans l'imaginaire occidental, ed. R. Deconinck, M. Watthee-Delmotte. Paris: L'Harmattan. 95-108.

Lateiner, D. 1989. The Historical Method of Herodotus. Toronto-Buffalo-London: University of Toronto Press.

Leiris, M. 1989. La possession et ses aspects théâtraux chez les Éthiopiens de Gondar. Paris: Fata Morgana.

Lévi-Strauss, C. 1979. La Voie des masques. Paris: Plon [1975¹].

Lévi-Strauss, C. 1989. Des symboles et leurs doubles. Paris: Plon.

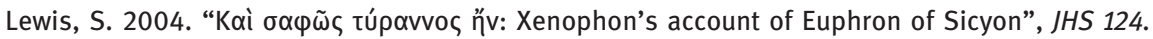
$65-74$.

Longo, V. 1963. "Deus ex machina e religione in Euripide." In Miscellanea N. Terzaghi. Genova: Istituto di filologia classica e medioevale. 237-248.

Lonsdale, S. H. 1993. Dance and Ritual Play in Greek Religion. Baltimore: John Hopkins UP.

Loraux, N. 1991. “Qu'est-ce qu'une déesse?” In Histoire des femmes I. L’Antiquité, ed. G. Duby; M. Perrot. Paris: Perrin. 31-62.

Mackey, J.L. 2006. "Saving the appearances: The Phenomenology of Epiphany in Atomist Theology. Princeton/Stanford Working Papers in Classics, URL: www.princeton.edu/ pswpc/ pdfs/mackey/050601.pdf.

Manni, E. 1952. Demetrio Poliorcete. Roma: Signorelli.

Marasco, G. 1980. "Filarco e la religione." Miscellanea in onore di Eugenio Manni IV. Roma: Bretschneider. 1389-1402.

Marasco, G. 1981. "Introduzione alla biografia plutarchea di Demetrio", Sileno 7. 35-70.

Mastrocinque, A. 1979. "Demetrios tragodoumenos (propaganda e letteratura al tempo di Demetrio Poliorcete)", Athenaeum 57. 260-276.

Mastronarde, D.J. 1990. "Actors on High: The Skene Roof, the Crane, and the Gods in Attic Drama”, ClAnt 9. 247-294.

Maurizi, N. 2003. "A propositi di oracoli e manifestazione prodigiose nel racconto erodoteo sulla tirannide pisistratide." In L'uso dei documenti nella storiografia antica, ed. A.M. Biraschi. Università di Perugia: Edizioni Scientifiche Italiane. 205-231.

Meyer, E. 1899. Forschungen zur alten Geschichte II. Halle: Niemeyer.

Mikalson, J. D. 1991. Honor thy Gods: Popular Religion in Greek Tragedy. Chapel Hill: University of North Carolina Press.

Moles, J. 2002. "Herodotus and Athens." In Brill's Companion to Herodotus, ed. E.J. Bakker et al. Leiden: Brill. 33-52.

Mueller, E. 1910. De Graecorum deorum partibus tragicis. RGVV 8.3. Giessen: Töpelmann.

Newiger, H.-J. 1990. "Ekkyklema und Mechane in der Inszenierung des griechischen Dramas", WürzJahrb 16. 33-42.

Nielsen, I. 2000. "Cultic Theatres and Ritual Drama in Ancient Greece", Proceedings of the Danish Institute at Athens 3. 107-133.

Pax, E. 1962. "Epiphanie.” RAC V. Stuttgart. 832-909.

Pédech, P. 1984. Trois historiens méconnus. Théopompe, Duris, Phylarque. Paris: Les Belles Lettres.

Peek, W. 1955. Griechische Vers-Inschriften I. Berlin: Akademie-Verlag.

Pelling, C. 2002. Plutarch and History: Eighteen Studies. Swansea: The Classical Press of Wales.

Pernot, L.; Lévy, C. 1997. Dire l'évidence. Paris: L'Harmattan. 
Petridou, G. 2015. Divine Epiphany in Ancient Greek Literature and Culture. Oxford: Oxford UP. Platt, V.J. 2011. Facing the Gods: Epiphany and Representation in Graeco-Roman Art, Literature and Religion. Greek Culture in the Roman World. Cambridge: Cambridge UP.

Préaux, Cl. 1978. Le Monde hellénistique. La Grèce et l'Orient, 323-146 av. J.-C., I. Paris: PUF.

Price, S.F.R. 1984. "Gods and Emperors: The Greek Language of the Roman Imperial Cult", JHS 104. $70-95$.

Prier, R.A. 1989. Thauma Idesthai. The Phenomenology of Sight and Appearance in Archaic Greek. Tallahassee: Florida State UP.

Pritchett, W. K. 1979. The Greek State at War, Part III: Religion. Berkeley: University of California Press.

Pritchett, W. K. 1993. The Liar School of Herodotos. Amsterdam: Gieben.

Pucci, P. 1994. "God's Intervention and Epiphany in Sophocles", AJPh 115. 15-46.

Raaflaub, K.A. 2002. "Philosophy, Science, Politics: Herodotus and the Intellectual Trends of his Time." In Brill's Companion to Herodotus, ed. E.J. Bakker et al. Leiden: Brill. 149-186.

Revermann, M. 2006. "The Competence of Theatre Audiences in Fifth- and Fourth-Century Athens", JHS 126. 99-124.

Robert, L. 1960. "Sur un papyrus de Paris. Glossaire latin-grec", Hellenica 11/12. 5-15.

Saïd, S. 2002. "Herodotus and Tragedy.” In Brill's Companion to Herodotus, ed. E.J. Bakker et al. Leiden: Brill. 117-147.

Santoro, M. 2000. [Demetrio Lacone], [La forma del dio]: PHerc. 1055, edizione, traduzione e commento. Napoli: Bibliopolis.

Scheer, T. S. 2000. Die Gottheit und ihr Bild: Untersuchungen zur Funktion griechischer Kultbilder in Religion und Politik. München: Beck.

Scott, K. 1928. "The Deification of Demetrius Poliorcetes", AJPh 49. 137-166.

Seaford, R. 1981. "Dionysiac Drama and the Dionysiac Mysteries”, CQ 31. 252-275.

Shimron, B. 1989. Politics and Belief in Herodotus. Stuttgart: Franz Steiner.

Sinos, R.H. 1993. "Divine Selection: Epiphany and Politics in Archaic Greece." In Cultural Poetics in Archaic Greece. Cult, Performance, Politics, ed. C. Dougherty, L. Kurke. Cambridge: Cambridge UP. 73-91.

Slings, S.R. 2002. "Oral Strategies in the Language of Herodotus." In Brill's Companion to Herodotus, ed. E.J. Bakker et al. Leiden: Brill. 53-77.

Sourvinou-Inwood, C. 1997. "Tragedy and Religion: Constructs and Readings." In Tragedy and the Historian, ed. C. Pelling. Oxford: Clarendon Press. 161-186.

Sourvinou-Inwood, C. 2003a. Tragedy and Athenian Religion. Lanham: Lexington Books.

Sourvinou-Inwood, C. 2003b. "Herodotos (and others) on Pelasgians: Some Perceptions of Ethnicity." In Herodotus and his World, ed. P. Derow, R. Parker. Oxford: Oxford UP. 103-144.

Stein, H. 1968. Herodotos. Erklärt von Heinrich Stein. Dublin-Zürich: repr. Weidmann [1883 $\left.{ }^{1}\right]$.

Strasburger, H. 19753. Die Wesenbestimmung der Geschichte durch die antike Geschichtsschreibung. Wiesbaden: Steiner (Studien II, 963-1016).

Tanner, J. 2006. The Invention of Art History in Ancient Greece: Religion, Society and Artistic Rationalisation. Cambridge: Cambridge UP.

Thomas, R. 1992. Literacy and Orality in Ancient Greece. Cambridge: Cambridge UP.

Thomas, R. 1993. "Performance and Written Publication in Herodotus and the Sophistic Generation." In Vermittlung und Tradierung von Wissen in der griechischen Kultur, ed. W. Kullmann, J. Althoff. Script-Oralia, 61. Tübingen: Gunter Narr. 225-244.

Thomas, R. 2000. Herodotus in Context: Ethnography, Science, and the Art of Persuasion. Cambridge: Cambridge UP.

Toffin, G. 1999. "Possession, danses masquées et corps divin dans la vallée de Katmandou (Népal)." In La possession en Asie du Sud. Parole, corps, territoire, ed. J. Assayag, G. Tarabout. Paris: EHESS. Purusartha 21. 237-261. 
Torraca, L. 1988. Duride di Samo. La maschera scenica nella storiografia ellenistica. Salerno: Laveglia.

Tuci, P.A. 2004. "Pisistrato e il 'demos': tentativi di manipolazione della voluntà popolare", RIL 138. $133-170$.

Turner, V. 1982. From Ritual to Theatre. The Human Seriousness of Play. New York: PAJ Publications.

Turner, V. 1986. The Anthropology of Performance. New York: PAJ Publications.

Ubersfeld, A. 1993. Lire le théâtre. Paris: Scandéditions/Éditions sociales.

Vernant, J.-P. 1981. "Le tyran boiteux: d'CEdipe à Périandre”, Le Temps de la réflexion 2. 235-255

(repr. J.-P. Vernant, P. Vidal-Naquet 1986. Edipe et ses mythes. Paris: La Découverte. 54-78).

Vernant, J.-P. 1986a. “Corps obscur, corps éclatant.” In Corps des dieux, ed. Ch. Malamoud, J.-P. Vernant. Le Temps de la réflexion 7. 19-45.

Vernant, J.-P. 1986b. "Le Dionysos masqué des Bacchantes d'Euripide." In Mythe et tragédie deux, ed. J.-P. Vernant, P. Vidal-Naquet. Paris: La Découverte. 237-270.

Wachsmuth, D. 1967. ПОМПIMOГ O $\triangle A I M \Omega N$. Untersuchung zu den antiken Sakrallandungen bei Seereisen. Berlin: Dissertation.

Weniger, L. 1923-1924. "Theophanien. Altgriechische Götteradvente”, ARW 22. 16-57.

Winkler, J.J.; Zeitlin, F.I. (ed.) 1989. Nothing To Do with Dionysos? Athenian Drama in its Social Context. Princeton: Princeton UP.

Zangara, A. 2007. Voir l'histoire: théories anciennes du récit historique lle siècle avant J.-C.-lle siècle après J.-C. Paris: Vrin.

Zanker, G. 1981. "Enargeia in the Ancient Criticism of Poetry", RhM 124. 297-311. 